NBER WORKING PAPER SERIES

\title{
ECONOMIC CONDITIONS AND \\ ALCOHOL PROBLEMS
}

Christopher J. Ruhm

Working Paper No. 4914

\section{NATIONAL BUREAU OF ECONOMIC RESEARCH \\ 1050 Massachusetts Avenue \\ Cambridge, MA 02138 \\ November 1994}

This paper is part of NBER's research program in Health Economics. Any opinions expressed are those of the author and not those of the National Bureau of Economic Research.

(C) 1994 by Christopher J. Ruhm. All rights reserved. Short sections of text, not to exceed two paragraphs, may be quoted without explicit permission provided that full credit, including () notice, is given to the source. 


\title{
ECONOMIC CONDITIONS AND \\ ALCOHOL PROBLEMS
}

\begin{abstract}
This study investigates the relationship between macroeconomic conditions and two alcohol-related outcomes -- liquor consumption and highway vehicle fatalities. Fixed-effect models are estimated for the 48 contiguous states over the 1975-1988 time period and withinstate variations are the focus of analysis. Alcohol consumption and traffic deaths vary procyclically, with a major portion of the effect of economic downturns attributed to reductions in incomes. The intake of hard liquor is the most sensitive to the state of the macroeconomy. There is no evidence, however, that fluctuations in economic conditions have a disproportionate impact on the drunk-driving of young adults.
\end{abstract}

\author{
Christopher J. Ruhm \\ Department of Economics \\ University of North Carolina Greensboro \\ Greensboro, NC 27412-5001 \\ and NBER
}




\section{Economic Conditions and Alcohol Problems}

Economic contractions are costly in many ways. Output declines and job losers must frequently accept positions which are substantially inferior to those departed. For instance, five years after permanent layoffs, displaced workers earn ten to thirteen percent less than if the employment termination had been avoided (Ruhm, 1991) and unemployed individuals frequently lose health insurance coverage (Horvath, 1987). Other, harder to quantify, costs may include reduced opportunities for promotions, deteriorating working conditions, decreases in wealth, and higher crime rates.

Local and national downturns may also adversely affect health. Seminal, but widely disputed, analysis by Harvey Brenner $(1975 \mathrm{a}, 1975 \mathrm{~b}, 1979)$ suggests that recessions are associated with higher admissions to mental hospitals and increased mortality due to cardiovascular disease, cirthosis, suicide, and homicide. Primary focus in this and related research is placed on psychological determinants, particularly increases in stress and risk-taking. The lack of attention to economic factors is surprising given the substantial investigation of medical care, lifestyle choices, and health outcomes in the context of human capital investments (e.g. Grossman, 1972) and, more recently, of the economic determinants of addictive behaviors (e.g. Becker \& Murphy, 1988; Akerlof, 1991; Chaloupka, 1991).

Economic models treat health as one argument in the utility function. Health status is . determined by stochastic shocks but also by economic factors such as changes in incomes and the relative price of medical care. Thus, health could deteriorate during economic slumps as earnings decrease and medical insurance is lost. However, since the utility function contains many other inputs, some of which indirectly affect health, it is possible that at least some aspects of health will improve. For example, ceteris paribus, falling incomes lower the consumption of 
normal goods such as drinking and driving, with the result that alcohol-involved traffic crashes may decline.' By contrast, research focusing on psychological responses to local or national recessions suggests that drinking will increase, as self-medication for stress, and that there may be higher levels of risky behaviors such as drunk-driving. ${ }^{2}$

This study investigates the relationship between economic conditions and two alcohol-related health outcomes -- liquor consumption and highway traffic deaths -- which provide information on different dimensions of the relationship between drinking and health. Increased alcohol consumption need not adversely affect health, if concentrated among light drinkers. Most available evidence (e.g. Coate \& Grossman, 1988), however, indicates that the demand of heavy drinkers is at least as responsive as that of recreational users to changes in prices and incomes. ${ }^{3}$ This suggests that drinking problems are likely to be closely related to average consumption levels. Motor vehicle fatalities are employed as an indicator of alcohol-involved driving. Traffic crashes are the leading cause of injury deaths in the United States. Approximately one-half of these fatalities are alcohol-related (Zobeck, et. al., 1991), as are two-thirds of those occurring at night (Heeren, et. al. 1985).

\footnotetext{
1 Skog (1986) or Wagenaar \& Streff (1989) provide evidence that liquor consumption is positively correlated with incomes.

2 For example, Brenner \& Mooney (1983, p. 1128) write: "recession increases the probability of a variety of losses and social changes that potentially threaten health. Attempts to alleviate psychological distress by medication with alcohol or legal and illegal drugs ... will tend to exacerbate existing morbidity and produce additional health problems." The psychological literature also allows for more complex labor market effects. For instance, some theories emphasize the stressful nature of employment, suggesting that increased job-holding might raise liquor consumption (e.g. Wilsnack \& Wilsnack, 1992 provide a summary of recent research examining the influence of employment on the drinking behavior of women).

3 Leung \& Phelps (1993) review recent research on the demand elasticity of alcohol consumption.
} 
Previous examinations of the relationship between health and the macroeconomy contain potentially serious methodological problems. In time series analyses, trends in economic conditions are likely to be spuriously correlated with noncontrolled for factors which influence health. Cross-sectional estimates also suffer from confounding, if unobservables affecting health are correlated with macroeconomic variables. As an alternative, this paper estimates fixed-effect (FE) models, using pooled time-series/cross-sectional data. Fixed-effect estimates reduce or eliminate the problem of confounding by exploiting within-state fluctuations in economic conditions which are independent of both national trends and cross-state differences in time-invariant unobservables affecting health.

\section{Methodological Issues}

Analyses using aggregate time-series data typically estimate some variant of the model:

$$
Y_{1}=\alpha+X_{1} \beta+Z_{1} \gamma+\varepsilon_{1}
$$

where $\mathrm{Y}$ measures health, $\mathrm{Z}$ is the indicator of economic conditions, $\mathrm{X}$ a vector of covariates, and $\varepsilon$ is an error term. For instance, in Brenner (1975a), health outcomes are proxied by mortality rates, $\mathrm{X}$ includes controls for incomes and government spending, and $\mathrm{Z}$ is a vector of current and lagged unemployment rates. Brenner uncovers a strong positive correlation between unemployment and mortality, leading him to conclude that health varies procyclically.

A number of researchers (Gravelle, et. al. , 1981; Stem, 1983; Wagstaff, 1985) have pointed out serious technical flaws in Brenner's analysis and later studies which correct for these problems (Forbes \& McGregor, 1984; McAvinchey, 1988; Joyce \& Mocan, 1993) fail to replicate his findings. Instead, the results are sensitive to the choice of countries, the proxies

4 Criticisms include Brenner's method of choosing lag lengths, the hypothesized pattern of lag 
used for health, and the time period analyzed. Significantly, elevated unemployment is frequently correlated with improvements rather than deteriorations in health. This fragility of results should not be surprising since research using time-series data contains a fundamental shortcoming which severely limits its usefulness. Any lengthy time-series is likely to contain omitted variables which are spuriously correlated with the regressors and outcome variables."

To show this concretely, assume that the "true" model is:

$$
Y_{1}=\alpha+X_{1} \beta+Z_{1} \gamma+Q_{1}+\phi_{1}
$$

where $Q$ is unobserved and $\phi$ is white noise. If $Z$ and $Q$ are related according to $Q_{t}=Z_{1} d+m_{t}$, where $m$ is uncorrelated with $Z$, then the error term in $(1)$ is $\varepsilon_{t}=Z_{t} \delta+\mu_{4}+\phi_{t}$ and the probability limit of $\hat{\gamma}$ (the estimated unemployment coefficient) is $\gamma+\delta$, which is upwards (downwards) biased if the unobserved factor is positively (negatively) correlated with Z.

Cross-sectional data suffer from a similar problem. For instance, Junankar (1991) estimates:

$$
Y_{i}=\alpha+X_{i} \beta+Z_{i} \gamma+\varepsilon_{i}
$$

where mortality rates are again the dependent variable and $i$ indicates a specific region/occupation population subgroup in Britain. $\hat{\gamma}$ is biased if demographic group unemployment rates are correlated with unobservables which influence mortality. In this example, unskilled blue collar workers are likely to experience the most joblessness but also to

coefficients, choice of covariates, and the plausibility of his results. For instance, the strongest effects on mortality are observed for infants and the elderly, groups for whom employment status should be a relatively less important determinant of health.

5 For example, much of the variation in unemployment during the four decades covered by Brenner's research is accounted for by dramatic reductions in joblessness following the end of the great depression. During this same period, mortality declined due to improvements in nutrition and increased availability of antibiotics. Failure to control for these factors leads Brenner to overstate the detrimental health impact of unemployment. 
have relatively high mortality rates due to factors such as lack of education or unhealthy lifestyles.

Some (but not all) important covariates can be controlled for if microdata is used, however, doing so introduces other problems. In particular, unemployment can no longer be considered exogenous, since poor health may cause rather than result from joblessness. ${ }^{6}$ Also, research which contrasts the health status of employed and nonemployed workers (e.g. Björkland 1985; Hammarström, et. al. 1988; Moser, et. al. 1984) will capture only a portion of the total impact of changes in economic conditions, since recessions affect a broad cross-section of the working and nonworking population, not just those individuals experiencing unemployment.

As an alternative, this paper estimates fixed-effect models using pooled data for the $\mathbf{4 8}$ contiguous states. The "true" model is assumed to be:

$$
Y_{i t}=\alpha_{i}+X_{i t} \beta+Z_{i t} \gamma+S_{i}+\lambda_{i t}
$$

where $Y_{i t}$ is the value of the dependent variable for state $i$ at time $t, Z$ the measure of economic conditions, $\mathrm{X}$ a vector of other covariates, and $\lambda$ is a "white noise" error term. The time-specific intercept, $\alpha$, accounts for time-varying characteristics which influence health and have changed in a uniform manner across the nation (e.g. changes in the maximum interstate highway speed limit). The state fixed-effect, $\mathrm{S}$, controls for factors which vary across states but remain fixed

- See Janlert, et. al. (1991) for evidence.

7 One advantage of microdata is that it will sometimes provide better (or at least different) information on the outcomes of interest. For instance, Kenkel (1993) and Mullahy \& Sindelar (1994) have used answers to questions in the 1985 and 1988 National Health Interview Surveys asking "how many times during the past year did you drive when you had perhaps too much to drink" to construct measures of drunk-driving. Since most instances of drunk-driving do not result in accidents, this variable is likely to pick up many cases of alcohol-involved driving not captured by vehicle fatality rates used in this paper. On the other hand, the self-reported measure is more likely to suffer from serious response biases. Consistent with the results reported below, both Kenkel and Mullahy \& Sindelar uncover a positive correlation between employment and drunk-driving. 
(within states) over time. $\hat{y}$ therefore measures the impact of intra-state deviations in economic conditions. Since the relative performance of state economies varies over time, the FE estimates largely avoid the aforementioned problems of confounding."

\section{Data}

The analysis below uses data for the 48 contiguous states over the 1975 through 1988 timie period. ${ }^{9}$ Two main outcomes are considered -- alcohol consumption and highway fatalities. Information on the per capita consumption of beer, wine, and distilled spirits are from the Brewer's Almanac, which is published annually by the U.S. Brewers' Association. ${ }^{10}$ These data are used to calculate the total consumption of alcohol, in gallons of ethanol, using conversion factors provided by the National Institute of Alcohol Abuse and Alcoholism's Alcohol Epidemiologic Data System.

Since relatively few states test all drivers involved in accidents for alcohol impairment, proxy measures for drunk driving are required. This analysis considers both the total fatality rate (TFR) and the night-time fatality rate (NFR), where the latter is defined to include deaths resulting from accidents occurring between midnight and 3:59 A.M. Although a larger percentage of night-time deaths involve alcohol, the number of such accidents is considerably smaller, reducing the reliability of the estimates. Thus, it is unclear which of the two measures is preferred. Traffic fatalities are also separately broken out for youths (15-20 and 21-24 year olds),

Fixed effect techniques were first used in alcohol research by Cook \& Tauchen $(1982,1984)$ to indicate the impact of liquor taxes on heavy drinking and minimum drinking ages on vehicle mortality. More recently, DuMouchel et. al. (1987) have employed FE models to evaluate the relationship between drinking ages and fatal crashes and Saffer \& Chaloupka (1989) to study the impact of preliminary breath test laws. Evans \& Graham (1988) provide a rare example of research using FE estimates to investigate the relationship between macroeconomic conditions and a health outcome (vehicle fatalities).

9 Hawaii, Alaska, and the District of Columbia are excluded.

10 I thank Frank Chaloupka for providing me with the data on liquor consumption, vehicle fatalities, minimum legal drinking ages, and beer taxes which are used in this analysis. 
in order to consider age-variations in the impact of economic conditions. Data on traffic fatalities are from the National Highway Traffic Safety Administration's Fatal Accident Reporting System .

Unemployment rates and the percentage of the population employed (hereafter referred to as the employment-to-population or EP ratio) are used as proxies for macroeconomic conditions. Unemployment rates furnish direct information on the ability of labor market participants to find jobs and have been widely utilized in previous research. EP ratios are used because some economists (e.g. Clark \& Summers, 1982) believe that they provide a more accurate measure of labor market conditions, particularly for groups such as young workers who frequently enter and exit the labor force. Unpublished data on unemployment rates and EP ratios were provided by the U.S. Bureau of Labor Statistics and refer to the noninstitutionalized civilian population aged 16 and over. Per capita incomes are sometimes controlled for, using U.S. Department of Commerce $(1989,1990)$ data. Some specifications are also estimated with the growth rate of Gross State Products (GSP) as the macroeconomic measure (with data obtained from the U.S. Department of Commerce 1988, 1991).

The tax rate on 24-12 ounce containers of beer is the proxy for alcohol prices. Data on beer taxes are from the Brewer's Almanac. Information on taxes, rather than prices, is used because the former are determined independently of liquor demand, whereas an outward shift in the demand curve will increase both the price of alcohol and the quantity consumed. "Numerous researchers have shown that higher alcohol taxes reduce drinking and related problems. ${ }^{12}$

"Saffer \& Grossman (1987) discuss this issue in greater detail.

12 Cook \& Moore (1993) provide a detailed discourse on alcohol taxation. 
The minimum legal drinking age (MLDA) is controlled for since it is negatively correlated with liquor consumption and drunk-driving (Coate \& Grossman, 1988; O'Malley \& Wagenaar, 1991) and exhibits considerable within-state variation during the sample period. ${ }^{13}$ The MLDA refers to purchases of beer with an alcohol content greater than $3.2 \%$. Data on drinking ages are obtained from Wagenaar (1981/2) and various issues of the National Highway Traffic Safety Administration's A Digest of State Alcohol-Highway Safety Laws. ${ }^{14}$

Table 1 presents sample means and standard deviations for important outcome and explanatory variables, weighted by the population of adults (aged 16 and over) in each state. Gross state products, per capita incomes, and beer taxes are in 1987 dollars, with the implicit price deflator used to adjust for price changes. Consumption of beer, distilled spirits, and wine are in actual gallons, while total alcohol consumption is measured in gallons of pure ethanol.

National trends in key variables are displayed in figure 1. Vehicle fatalities and alcohol consumption peak part way into the sample period (1979 and 1981 respectively), legal drinking ages increase monotonically over time, and unemployment rates are unusually high during the recessions of the middle 1970 s and early 1980s. The figure does not reveal any obvious relationship between national unemployment rates and alcohol outcomes. However, the impact of macroeconomic factors could be masked by strong time trends in drinking or drunk-driving, which mask the impact of fluctuations in the (national) macroeconomy.

FE models rely on within-state variations in economic conditions and have the potential for improving on (aggregate) timie-series analyses if there are substantial economic fluctuations

\footnotetext{
13 Twenty-eight states raised the legal drinking age between 1976 and 1988, a dramatic reversal of the downward trend observed during the early 1970 s.

Weighted averages are used to reflect changes in state beer taxes or MLDAs occurring during the middle of calendar years.
} 
across states. To show that this condition is met, table 2 presents the squared correlation coefficient $\left(R^{2}\right)$ between individual states and the entire nation for unemployment rates, EP ratios, and changes in Gross Domestic Products. In the case of unemployment, the $\mathrm{R}^{2}$ is below $0.5(0.75)$ for 21 (33) of the 48 states. Similarly, the $R^{2}$ is lower than $0.5(0.75)$ for $9(25)$ states for EP ratios and for 20 (32) states when considering gross domestic products.

Further evidence of the dispersion in economic performance is provided in figures 2 through 4, which display unemployment rates, EP ratios, and changes in Gross Domestic Products for the US and for four large states -- California, Illinois, New York, and Texas. The figures show relative deterioration, over the sample period, in the economies of Illinois and Texas and contrasting improvement in California and New York. This reflects the healthy economic growth on the two coasts and stagnation in the middle of the country occurring during this time period.

\section{Econometric Analysis}

This section presents econometric estimates of the relationship between macroeconomic conditions and alcohol-related outcomes. Most of the results are for fixed-effect models. Equations which exclude state and time dummy variables and those using national data are also included for comparison purposes. When considering drinking, the dependent variable is the natural $\log$ of gallons consumed. Since vehicle mortality is a rate, restricted to the range zero through one, logit models are estimated for this outcome. The dependent variable in the logit model is the natural logarithm of the odds ratio. For instance, if $Y_{i s}$ is the traffic fatality rate, the regressand is $y_{i t}=\ln \left[Y_{i t}\left(1-Y_{i t}\right)^{-1}\right]$. The error term is heteroscedastic, with variance $\left[Y_{i \mathfrak{i l}}\left(1-Y_{k t}\right) n_{i t}\right]^{-1}$, 
for $n_{u}$ the population of state $i$ at time $t$. Efficiency is therefore maximized by using weighted least squares, with cell weights $\left[Y_{\mathrm{it}}\left(1-\mathrm{Y}_{\mathrm{i}}\right) \mathrm{n}_{\mathrm{it}}\right]^{1 / 2}$.

\subsection{Unemployment Rates and Alcohol Outcomes}

Alternative specifications of a basic equation comparing unemployment rates (UN) and alcohol outcomes $(Y)$ are shown on table 3. The first column presents resuits of the model:

$$
Y_{1}=\alpha+\mathrm{UN}_{\mathrm{t}} \gamma+\mathrm{T} \delta+\varepsilon_{\mathrm{t}}
$$

estimated using time-series data for the entire United States, with $\mathrm{T}$ a quadratic time trend. This corresponds to the methodology of previous research using aggregated data. As discussed, $\hat{\gamma}$ is likely to be biased due to spurious correlation between unobservable characteristics and unemployment rates. The second column displays estimates of:

$$
Y_{i t}=\alpha+U N_{i t} \gamma+T \delta+\varepsilon_{i t}
$$

which uses pooled state-level data. Equation (6) is roughly analogous to prior studies employing cross-sectional information. Column c) is the same as b), except that the time trend is replaced with a set of year dummy variables, thus holding constant time-varying national factors which influence alcohol outcomes. ${ }^{\text {s }}$ The last two columns present results for fixed effect models, which include a vector of state dummy variables. They differ in that column e) controls for the beer tax rate and MLDA, whereas column d) does not.

The unemployment coefficients are sensitive to the specification chosen. FE estimates indicate that increases in a state's unemployment rate are correlated with lower alcohol consumption and fewer vehicle fatalities (see columns $d$ and e). ${ }^{16}$ Substantially different results

is For instance, changes in U.S. economic conditions or in the national sentiment towards drunk driving are controlled for.

${ }^{16}$ I also estimated a series of logit models where the dependent variable was the mortality rate due to cirrhosis of the liver. In this case, fixed-effect estimates fail to reveal a statistically 
are obtained when considering national or cross-state variations. For instance, U.S.

uncmployment rates are uncorrelated with alcohol consumption (column a), whereas the negative association is overstated when focusing upon differences between states (columns b and c). As mentioned above, the former occurs because the strong concave trend in liquor consumption dominates any national business cycle effect. The latter is observed because liquor intake is persistently high (but presumably for reasons unrelated to economic conditions) in states with relatively elevated unemployment rates. These findings highlight the importance of using data containing multiple observations for each time period and controlling for unobserved fixed effects.

As other researchers have found, beer taxes and MLDAs are inversely related to liquor consumption and vehicle fatality rates (see column e). Comparison of columns d) and e) shows, however, that the addition of these two key alcohol policies has virtually no impact on the estimated unemployment coefficients. This suggests that FE estimates of macroeconomic effects are robust to the choice of supplemental covariates.

\subsection{Fixed-Efrect Estimates}

The econometric estimates in the remainder of the paper are variants of the FE model:

$$
Y_{i t}=\alpha_{i}+X_{i n} \beta+Z_{i j} \gamma+S_{i}+\lambda_{i t}
$$

$Y_{U}$ represents the dependent variable for state $i$ at time $t, Z$ includes contemporaneous and sometimes lagged values of state economic conditions, $\alpha$ is a time-specific intercept (a vector of time dummy variables), $\mathrm{S}$ a time-invariant state effect (a vector of state dummy variables), $\mathrm{X}$ are the other covariates, and $\lambda$ is the error term. Included in $\mathrm{X}$ are beer taxes, the MLDA, and, in some specifications, per capita personal incomes.

significant effect of changes in joblessness. 
Adding personal incomes to the set of explanatory variables will shift $\hat{y}$ towards zero if economic contractions partially affect alcohol outcomes by reducing earnings. The income coefficient is likely to understate the role of economic factors, however, because it does not account for changes in relative prices (e.g. the increased cost of medical care if employer-based health insurance is curtailed) or in the income distribution. Therefore, the unemployment coefficient continues to reflect both psychological influences and economic factors other than average incomes.

Table 4 presents FE estimates with the unemployment rate used as the proxy for economic conditions and alternative lag specifications allowed for. There is little evidence that the inclusion of lagged regressors substantially improves the predictive power of the models. Previous unemployment is unrelated to alcohol consumption. For vehicle fatalities, the first and second lags have offsetting effects, with the result that the parameter on the current unemployment rate with lags excluded (column a) is virtually identical to the sum of the coefficients on $\mathrm{UN}_{1.2}$ through $\mathrm{UN}_{1}$, when all three are controlled for (column c). The remainder of the analysis therefore focuses on contemporaneous effects.

Alcohol consumption and vehicle deaths are procyclical. The estimates in column a) indicate that raising the unemployment rate from its mean value to one standard deviation above it (an increase of 2.12 percentage points) lowers predicted drinking by $1.3 \%$ and decreases traffic deaths by almost $7 \% .{ }^{17}$ The importance of economic determinants is highlighted by noting that the unemployment coefficients are reduced by more than one-third for traffic fatalities and over two-thirds for liquor consumption when per capita incomes are controlled for (see column d).

17 Evaluating the other regressors at their sample means, the expected vehicle fatality rate declines from 2.03 to 1.89 per 10,000 persons. 
Furthermore, earnings are strongly positively correlated with both outcomes. For example, a one standard deviation increase in the state unemployment rate lowers predicted drinking by just $0.4 \%$ in column d) versus $1.3 \%$ in column a). Ceteris paribus, a $\$ 1000$ reduction in personal incomes decreases expected liquor consumption by $1.5 \%$.

The finding that drinking and traffic fatalities are positively related to economic conditions is robust to changes in the method of measuring the latter. For instance, substantially analogous results are obtained when the employment-to-population ratio, rather than the unemployment rate, is controlled for. As shown in table 5, rising EP ratios are associated with increased consumption of alcohol and higher vehicle fatality rates (e.g. a one point rise in the percentage of the population employed elevates predicted liquor consumption by $.8 \%$, versus the $.6 \%$ increase expected if the unemployment rate falls by one percentage point). Much of the business cycle effect is again the result of income changes and the latter are positively correlated with both outcomes. Thus, the unemployment coefficient is cut approximately in half when personal incomes are controlled for and a $\$ 1000$ increase in incomes is expected to raise alcohol consumption by $1.2 \%$. Similar results were obtained for a series of equations (not displayed) with changes in Gross State Products as the macroeconomic variable -- the growth rate of GSP is positively related to both alcohol consumption and traffic deaths.

\subsection{Alcohol Consumption}

The effects of the economic conditions on drinking vary markedly with the type of alcoholic beverage considered. This is shown in table 6, which displays separate fixed-effect estimates for the consumption of beer, distilled spirits, and wine. The intake of hard liquor is by far the most sensitive to the state of the economy. A one percentage point increase in the state unemployment rate lowers the predicted consumption of spirits by over $1.1 \%$, compared to just 
$0.4 \%$ for beer or wine (column a). A corresponding one percentage point reduction in the EP ratio decreases the expected intake of spirits, beer, and wine by $1.3 \%, 0.5 \%$, and $0.9 \%$ respectively (column c).

The strong response of spirits consumption to macroeconomic conditions largely results from its relatively high income elasticity. A \$1000 decrease in personal incomes lowers the drinking of distilled liquor by between $2.2 \%$ and $2.3 \%$, depending on whether the unemployment rate (column b) or EP ratio (column d) is controlled for, whereas the decline is just $0.9 \%$ to $1.3 \%$ for beer and $-0.5 \%$ to $0.5 \%$ for wine. ${ }^{18}$ One possibility is that reduced incomes decrease the relative demand for spirits because individuals shift drinking away from bars and restaurants, where liquor is relatively expensive and spirits are disproportionately imbibed, and towards consumption in the home, where beer is the drink of choice. ${ }^{19}$ To the extent that off-premise drinking is no longer followed by driving, this may help to explain the fall in alcohol-involved vehicle fatalities observed during downturns.

\subsection{Motor Vehicle Fatallties}

Further detail on traffic deaths is obtained by providing results for night-time, as well as total, fatalities and separate estimates for youths aged 15-20 and 21-24. Although teenagers and young adults are more than twice as likely as older persons to die in traffic accidents and are involved in fatal night-time crashes three times as often (see table 1), there has been no previous analysis of whether the sensitivity of drunk-driving to economic conditions varies with age.

18 Chaloupka \& Saffer (1990) present evidence that price elasticities are higher for distilled spirits than for wine or beer, further indicating the relative sensitivity of spirits consumption to economic factors.

19 Average prices (per ounce of ethanol) of spirits are over twice as high as for wine and more than $70 \%$ above those of beer; alcohol is more than three times as costly on-premise as off-premise, with the greatest differential observed for spirits (Treno, et. al., 1993). Thus, when incomes fall, substitution is likely to occur away from spirits and towards off-premise use. 
Results of the vehicle fatality equations are summarized in table 7, with unemployment rates are controlled for. Similar findings were obtained when EP ratios were used to proxy the macroeconomy. ${ }^{20}$ Bracketed entries show estimated elasticities of traffic deaths to changes in the unemployment rate, calculated as $\varepsilon_{j}=(1-\tilde{P}) \hat{\beta}_{j} \bar{X}_{j}$, for $\hat{\beta}_{j}$ the logit coefficient on the jth regressor and $\bar{X}_{j}$ and $\bar{P}$ the sample means of the jth explanatory variable and motor vehicle death rate respectively.

Although both types of traffic mortality decline as the macroeconomy worsens, the reduction in night-time deaths is only about half as large as for total fatalities. Thus, a one standard deviation increase in the unemployment rate is associated with a 7\% lower TFR (from 23.0 to 18.9 per 100,000 persons) but with just a $3 \%$ reduction in the NFR (from 4.16 to 4.04 deaths per 100,000$)$. Much of this difference is likely to reflect cyclical changes in driving patterns, whereby commuting to work and daytime pleasure driving are disproportionately reduced during economic contractions. Even when measured by the NFR, however, there is a small but statistically significant reduction in drunk-driving when the economy deteriorates.

The pattems for 21-24 year olds are similar to those for the whole population, with modest evidence of greater cyclicality of night-time fatalities. The elasticity of the NFR to the unemployment rate is .098 for the full sample, compared to .117 for those aged $21-24$. By contrast, total and night-time traffic fatalities of 15-20 year olds are less sensitive to changes in the macroeconomy than those of all adults or of 21-24 year olds. For example, the unemployment elasticity of the TFR is .23 for both the full population and those aged 21 to 24 , versus .15 for 15-20 year olds (columina).

20 The main difference is even stronger evidence of procyclical changes in night-time fatalities for the all individuals and for 21 to 24 year olds. 
Disparate income effects account for at least some of the difference across age groups. Night-time vehicle deaths rise with incomes for 21-24 year olds and for the entire population but fall for those aged 15-20. ${ }^{21}$ Holding incomes constant, the NFR of 15-20 year olds is actually the most responsive to changes in unemployment rates -- elasticities are .111 and .084 , respectively, for 15-20 and 21-24 year olds, and .068 for all adults (column d). As discussed above, the consumption of spirits is particularly sensitive to the state of the economy. Since hard liquor is disproportionately consumed on-premise and by mature adults, a decrease in incomes may therefore cause a relatively large reduction in drinking in commercial establishments and in the subsequent alcohol-involved driving of older persons. By contrast, youths primarily purchase beer for off-premise use and its consumption is relatively insensitive to macroeconomic conditions. $^{22}$

\section{Conclusion}

This study investigates the relationship between macroeconomic conditions and two alcohol-related health outcomes - liquor consumption and highway vehicle fatalities. Fixed-effect models are estimated for 48 contiguous states over the 1975-1988 period. The analysis focuses upon within-state differences in economic conditions and most specifications include controls for individual year effects, beer taxes, and the minimum legal drinking age. Per

21 These results must be interpreted cautiously, since the null hypothesis of no income effect can not be rejected at the .05 level for any of the three groups.

22 For instance, in data from the Alcohol Supplement to the 1988 National Health Interview Survey (provided to me Gerald Williams of the Alcohol Epidemiologic Data System), $77 \%$ of 18-20 year old male drinkers report a preference for beer and only 10\% for spirits. For 35-54 year old men the corresponding figures are $52 \%$ and $28 \%$, respectively, and for men over the age of $75,30 \%$ and $48 \%$. Women are less likely to prefer beer at all ages but the same pattern of relative preferences is observed. 
capita personal incomes are sometimes held constant, to provide a crude indication of the portion of the total business cycle effect accounted for by changes in eamings.

Fixed-effect specifications avoid many of the spurious correlation problems present in aggregate time-series or cross-sectional data. Comparison of results obtained for the three types of estimates shows that these biases are empirically important. For instance, the response of alcohol consumption to changes in unemployment rates is understated when using national time-series data. This occurs because liquor intake exhibits a strong concave time trend, during the period of analysis, which dominates any effect of fluctuations in the national economy. Conversely, macroeconomic effects are overestimated when pooled data are utilized but state fixed-effects are not controlled for.

There is no evidence that drinking or risky driving rises during economic downturns. Instead, liquor consumption and alcohol-involved driving, as measured by either total or night-time vehicle fatalities, vary procyclically. A large proportion of the total impact can be traced to fluctuations in incomes, which demonstrates that drinking and driving are normal goods. Although liquor may be used as self-medication for increased stress, in aggregate, this effect is more than offset by lower incomes and (possibly) changes in relative prices.

Two other findings are noteworthy. First, the consumption of distilled spirits is more sensitive to changes in the macroeconomy than is the drinking of either beer or wine. Second, although youths have much higher vehicle death rates than their older counterparts, there is no indication of greater responsiveness to economic conditions. Drinking patterns may explain these results. During downturns, consumers are likely to shift to cheaper sources of alcohol -from hard liquor to wine and beer and from bars and restaurants to drinking in the home. These 
movements will be less pronounced for youths, since most of their liquor intake is of beer and on an off-premise basis during all periods.

The investigation supplies strong evidence that economic conditions influence alcohol-related health outcomes through their impact on personal incomes and (possibly) relative prices. This finding may have implications for public policy. 


\section{References}

Akerlof, George A. 1991. "Procrastination and Obedience" American Economic Review, Vol. 81, No. 2, May, pp. 1-19.

Becker, Gary S. and Kevin M. Murphy. 1988. "A Theory of Rational Addiction" Journal of Political Economy, Vol. 96, No. 4, pp. 675-700.

Björkland, Anders. 1985. "Unemployment and Mental Health: Some Evidence From Panel Data", Journal of Human Resources, Vol. 20, No. 4, Fall, pp. 469-83.

Brenner, M. Harvey. 1975. "Mortality and the National Economy" The Lancet, September 15, pp. 568-73. (1975a)

Brenner, M. Harvey. 1975. "Trends in Alcohol Consumption and Associated Illnesses: Some Effects of Economic Changes" The American Journal of Public Health, Vol. 65, No. 12, December, pp. 1279-92. (1975b)

Brenner, M. Harvey. 1979. "Influence of Social Environment on Psychopathology: The Historic Perspective", in James E. Barret et. al. (eds.) Stress and Mental Disorder. New York: Raven Press, pp. 161-77.

Brenner, M. Harvey and Anne Mooney. 1983. "Unemployment and Health in the Context of Economic Change" Social Science Medicine, Vol. 17, No. 16, pp. 1125-38.

Chaloupka, Frank J. 1991. "Rational Addictive Behavior and Cigarette Smoking" Journal of Political Economy, Vol. 99, No. 4, pp. 722-742.

Clark, Kim B. and Lawrence H. Summers. 1982. "The Dynamics of Youth Unemployment" in David A. Wise (ed.) The Youth Labor Market Problem: Its Nature, Causes, and Consequences. Chicago: University of Chicago Press, pp. 199-230.

Coate, Douglas and Michael Grossman. 1988. "Effects of Alcohol Beverage Prices and Legal Drinking Ages on Youth Alcohol Use" Journal of Law and Economics, Vol. 31, No. 1, pp. $145-72$.

Cook, Philip J. and Michael J. Moore. 1993. "Taxation of Alcoholic Beverages" in Michael Hilton and Gregory Bloss (eds.) Economics and the Prevention of Alcohol-Related Problems. Rockville, MD: U.S. Department of Health and Human Services (N.I.H. Publication No. 93-3513), pp. 33-58.

Cook, Philip J. and George Tauchen. 1982. "The Effect of Liquor Taxes on Heavy Drinking" Bell Journal of Economics, Vol. 13, No. 4, Autumn, pp. 379-90. 
Cook, Philip J. and George Tauchen. 1984. "The Effect of Minimum Drinking Age Legislation on Youthful Auto Fatalities, 1970-77" Journal of Legal Studies, Vol. 13, January, pp. $169-90$.

DuMouchel, William, Allan F. Williams, and Paul Zador. 1987. "Raising the Alcohol Purchase Age: Its Effects on Fatal Motor Vehicle Crashes in Twenty-Six States" Journal of Legal Studies, Vol. 16, January, pp. 249-66.

Evans, William and John D. Graham. 1988. "Traffic Safety and the Business Cycle" Alcohol, Drugs, and Driving, Vol. 4, No. 1, pp. $31-8$.

Forbes, John F. and Alan McGregor. 1984. "Unemployment and Mortality in Post-War Scotland" Journal of Health Economics, Vol. 3, pp. 219-57.

Gravelle, H.S.E., G. Hutchinson, and J. Stem. 1981. "Mortality and Unemployment: A Critique of Brenner's Time Series Analysis" The Lancet, 9/26, pp. 675-9.

Grossman, Michael M. 1972. "On the Concept of Health Capital and the Demand for Health" Journal of Political Economy, Vol. 80, No. 2, pp. 223-55.

Hammarstrōm, Anne, Urban Janlert, and Töres Theorell. 1988. "Youth Unemployment and III Health: Results from a 2-year Follow-up Study" Social Science Medicine, Vol. 26, No. 10, pp. 1025-33.

Herren, Timothy, Robert A. Smith, Suzette Morelock, and Ralph Hingson. 1985. "Surrogate Measures of Alcohol Involvement in Fatal Crashes: Are Conventional Indicators Adequate?" Journal of Safety Research, Vol. 16, No. 3, fall, pp. 127-34.

Horvath, Frances W. 1987. "The Pulse of Economic Change: Displaced Workers of 1981-85" Monthly Labor Review, Vol. 110, June, pp. 3-12.

Janlert, Urban, Kjell Asplund, and Lars Weinehall. 1991. "Unemployment and Cardiovascular Risk Indicators" Scandanavian Joumal of Social Medicine, Vol. 20, No. 1, March, pp. 14-18.

Joyce, Theodore and Naci Mocan. 1993. "Unemployment and Infant Health: Time-Series Evidence from the State of Tennessee" Journal of Human Resources, Vol. 28, No. 1, Winter, pp. 185-203.

Junankar, P.N. 1991. "Unemployment and Mortality in England: A Preliminary Analysis" Oxford Economic Papers, Vol. 43, No. 2, pp. 305-20.

Kenkel, Donald S. 1993. "Drinking, Driving, and Deterrence: The Effectiveness and Social Costs of Alternative Policies" Journal of Law and Economics, Vol. 36, October, pp. 877-913. 
Leung, Siu Fai and Charles E. Phelps. 1993. "My Kingdom for a Drink...7: A Review of Estimates of the Price Sensitivity of Demand for Alcoholic Beverages" in Michael E. Hilton and Gregory Bloss (eds.), Economics and the Prevention of Alcohol-Related Problems. Rockville, MD: U.S. Department of Health and Human Services (N.I.H. Publication No. 93-3513), pp. 1-31.

McAvinchey, Ian D. 1988. "A Comparison of Unemployment, Income, and Mortality Interaction for five European Countries" Applied Economics, Vol. 20, No. 4, pp. 453-71.

Moser, K.A., A.J. Fox, and D.R. Jones. 1984. "Unemployment and Mortality in the OPCS Longitudinal Study" The Lancet, 12/8, pp. 1324-8.

Mullahy, John and Jody L. Sindelar. 1994. "Do Drinkers Know When to Say When? An Empirical Analysis of Drunk Driving" Economic Inquiry, Vol. 32, No. 3, July, pp. 383-95.

O'Malley, Patrick M.. and Alexander C. Wagenaar. 1991. "Effects of Minimum Drinking Age Laws on Alcohol Use, Related Behaviors, and Traffic Crash Involvement Among American Youth 1976-1987" Journal of Studies on Alcohol, Vol. 52, No. 5, pp. 478-91.

Ruhm, Christopher J. 1991. "Are Workers Permanently Scarred By Job Displacements" American Economic Review, Vol. 81, No. 1, March, pp. 319-24.

Saffer, Henry and Frank Chaloupka. 1989. "Breath Testing and Highway Fatality Rates" Applied Economics, Vol. 21, No. 7, pp. 901-912.

Saffer, Henry and Frank Chaloupka. 1990. "Tax Differentials and Commodity Substitution: The Case of Beer, Wine and Spirits", mimeo, June.

Saffer, Henry, and Michael Grossman. 1987. "Beer Taxes, The Legal Drinking Age, and Youth Motor Fatalities" Journal of Legal Studies, Vol. 16, June, pp. 351-74.

Skog, Ole-Jørgen. 1986. "An Analysis of Divergent Trends in Alcohol Consumption and Economic Development" Joumal of Studies on Alcohol, Vol. 47, No. 1, pp. 19-25.

Stem, J. 1983. "The Relationship between Unemployment, Morbidity, and Mortality in Britain", Population Studies, Vol. 37, pp. 61-74.

Treno, Andrew J., Thomas M. Nephew, William R. Ponicki, and Paul J. Gruenewald. 1993. "Alcohol Beverage Price Spectra: Opportunities for Substitution" Alcoholism: Clinical and Experimental Research, Vol. 17, No. 3, pp. 675-80.

U.S. Brewers' Association. various years. The Brewer's Almanac. Washington D.C.: U.S. Brewers' Association.

U.S. Department of Commerce. 1988. "Gross State Product by Industry, 1963-86" Survey of Current Business, Vol. 68, No. 5, May, pp. 30-46. 
U.S. Department of Commerce. 1989. State Personal Income: 1929-87. Washington D.C.: U.S. Government Printing Office.

U.S. Department of Commerce. 1990. Statistical Abstract of the United States: 1990. Washington D.C.: U.S. Govemment Printing Office.

U.S. Department of Commerce. 1991. "Gross State Product by Industry, 1977-89" Survey of Current Business, Vol. 71, No. 12, December, pp. 43-59.

U.S. Department of Transportation, National Highway Traffic Safety Administration. Various Years. A Digest of State Alcohol-Highway Safety Laws. Washington D.C.: U.S.

Government Printing Office.

Wagenaar, Alexander C. 1981/2. "Legal Minimum Drinking Age Changes in the United States: 1970-1981" Alcohol Health and Research World, Winter, pp. 21-26.

Wagenaar, Alexander C. and Frederick M. Streff. 1989. "Macroeconomic Conditions and Alcohol-Impaired Driving" Journal of Studies on Alcohol, Vol. 50, No. 3, pp. 217-25.

Wagstaff, Adam. 1985. "Time Series Analysis of the Relationship Between Unemployment and Mortality: A Survey of Econometric Critiques and Replications of Brenner's Studies" Social Science Medicine, Vol. 21, No. 9, pp. 985-96.

Wilsnack, Richard W. and Sharon C. Wilsnack. 1992. "Women, Work, and Alcohol: Failure of Simple Theories" Alcoholism: Clinical and Experimental Research, Vol. 16, No. 2, April, pp. 172-9.

Zobeck, Terry S., Steven D. Elliott, and Darryl Bertolucci. 1991. Trends in Alcohol-Related Fatal Traffic Crashes, United States: 1977-1989, Washington, D.C.: National Institute on Alcohol Abuse and Alcoholism, Surveillance Report \#19, November. 
Table 1:

Description of and Summary Statistics on Variables Used in Analysis

\begin{tabular}{lcc} 
Variable & $\begin{array}{c}\text { Sample } \\
\text { Mean }\end{array}$ & $\begin{array}{c}\text { Standard } \\
\text { Deviation }\end{array}$ \\
\hline
\end{tabular}

\section{Outcome Variables}

Per Capita Alcohol Consumption in Gallons (Source: Brewer's Almanac)

Total Alcohol Consumption (Ethanol Equivalents)

$2.08 \quad 0.40$

Beer Consumption

$23.49 \quad 3.61$

Distilled Spirits Consumption

$1.83 \quad 0.51$

Wine Consumption

2.10

1.10

Vehicle Fatality Rate (Source: Fatal Accident Reporting System)

Total Vehicle Fatality Rate (TFR)

Night-time Vehicle Fatality Rate (NFR)

TFR: 15 to 20 year olds

TFR: 21 to 24 year olds

NFR: 15 to 20 year olds

NFR: 21 to 24 year olds
$2.03 \mathrm{E}-4 \quad 5.57 \mathrm{E}-5$

4.16E-5 1.16E-5

4.18E-4 1.12E-4

3.95E-4 $\quad 1.08 \mathrm{E}-4$

$1.20 \mathrm{E}-4 \quad 3.96 \mathrm{E}-5$

1.30E-4 3.41E-5

\section{Explanatory Variables}

Civilian Unemployment Rate in \% (Source: Unpublished BLS data)

$7.34 \% \quad 2.12 \%$

\% of Civilian Population Employed (Source: Unpublished BLS data)

$59.25 \% \quad 3.92 \%$

Change in Real Gross State Product

(Source: Survey of Current Business 1988, 1991)

$2.75 \% \quad 3.77 \%$

Per Capita Income in $\$ 1987$ (Source: State Personal Income:

1929-87, Statistical Abstract of the United States: 1990)

Tax in $\$ 1987$ on 24 - 12 oz. containers of Beer

$\$ 14,054 \quad \$ 2,071$

(Source: Brewer's Almanac)

$\$ 0.56$

$\$ 0.63$

Minimum Legal Drinking Age in Years (Source: Wagenaar 1981/2; A Digest of State Alcohol-Highway Safety Related

20.14

1.22 Legislation)

Note: Summary statistics are weighted by the population of noninstitutionalized persons in the state aged 16 and over. 
Table 2: Squared Correlation Coefficlent Between State and National Economic Conditions

\begin{tabular}{|c|c|c|c|c|c|c|c|}
\hline State & $\begin{array}{c}\text { Unem- } \\
\text { ployment } \\
\text { Rate }\end{array}$ & $\begin{array}{c}\text { Employment } \\
\text { to Population } \\
\text { Ratlo }\end{array}$ & $\begin{array}{c}\Delta \text { In Gross } \\
\text { Domestic } \\
\text { Product }\end{array}$ & State & $\begin{array}{l}\text { Unem- } \\
\text { ployment } \\
\text { Rate }\end{array}$ & $\begin{array}{c}\text { Employment } \\
\text { to Population } \\
\text { Ratlo }\end{array}$ & $\begin{array}{c}\Delta \text { In Gross } \\
\text { Domestle } \\
\text { Product }\end{array}$ \\
\hline Alabana & 0.62 & 0.67 & 0.90 & Nebraska & 0.48 & 0.73 & 0.45 \\
\hline Arizona & 0.52 & 0.69 & 0.66 & Nevada & 0.84 & 0.75 & 0.42 \\
\hline Arkansas & 0.55 & 0.72 & 0.81 & New Hampshire & 0.63 & 0.88 & 0.42 \\
\hline California & 0.82 & 0.96 & 0.73 & New Jersey & 0.36 & 0.91 & 0.45 \\
\hline Colorado & 0.14 & 0.19 & 0.21 & New Mexico & 0.40 & 0.60 & 0.02 \\
\hline Connecticut & 0.33 & 0.87 & 0.63 & New York & 0.41 & 0.93 & 0.41 \\
\hline Delaware & 0.27 & 0.77 & 0.28 & North Carolina & 0.92 & 0.66 & 0.75 \\
\hline Florida & 0.51 & 0.83 & 0.55 & North Dakota & 0.17 & 0.79 & 0.01 \\
\hline Georgia & 0.64 & 0.96 & 0.78 & Ohio & 0.86 & 0.73 & 0.96 \\
\hline Idaho & 0.54 & 0.41 & 0.65 & Oklahoma & 0.13 & 0.51 & 0.01 \\
\hline Illinois & 0.61 & 0.62 & 0.83 & Oregon & 0.89 & 0.80 & 0.80 \\
\hline Indiana & 0.68 & 0.49 & 0.91 & Pennsylvania & 0.86 & 0.83 & 0.78 \\
\hline Iowa & 0.51 & 0.40 & 0.63 & Rhode Island & 0.49 & 0.81 & 0.70 \\
\hline Kansas & 0.50 & 0.66 & 0.49 & South Carolina & 0.95 & 0.50 & 0.83 \\
\hline Kentucky & 0.32 & 0.02 & 0.79 & South Dakota & 0.45 & 0.87 & 0.27 \\
\hline Louisiana & 0.02 & 0.19 & 0.00 & Tennessee & 0.78 & 0.69 & 0.83 \\
\hline Maine & 0.48 & 0.72 & 0.41 & Texas & 0.03 & 0.55 & 0.03 \\
\hline Maryland & 0.55 & 0.92 & 0.56 & Utah & 0.75 & 0.81 & 0.55 \\
\hline Massachusetts & 0.34 & 0.85 & 0.56 & Vermonth & 0.39 & 0.81 & 0.47 \\
\hline Michigan & 0.81 & 0.68 & 0.84 & Virginia & 0.75 & 0.77 & 0.64 \\
\hline Minnesota & 0.85 & 0.83 & 0.83 & Washington & 0.93 & 0.85 & 0.60 \\
\hline Mississippi & 0.32 & 0.18 & 0.58 & West Virginia & 0.47 & 0.00 & 0.44 \\
\hline Missouri & 0.79 & 0.83 & 0.87 & Wisconsin & 0.78 & 0.57 & 0.83 \\
\hline Montanna & 0.47 & 0.76 & 0.06 & Wyoming & 0.06 & 0.03 & 0.00 \\
\hline
\end{tabular}


Table 3: Econometric Estimates of the Relationship Between National or State Unemployment Rates and Alcohol Outcomes

\begin{tabular}{lccccc} 
Regressor & (a) & (b) & (c) & (d) & (e) \\
\hline \multicolumn{1}{c}{ Total Alcohol Consumption } \\
& & & & & \\
National Unemployment & -.0013 & & & & \\
Rate & $(0.20)$ & & & & \\
State Unemployment Rate & & -.0105 & -.0148 & -.0055 & \\
& & $(2.97)$ & $(3.45)$ & $(5.49)$ & $(6.69)$ \\
Time & .0318 & .0356 & & & \\
Time Squared & $(3.73)$ & $(4.36)$ & & & -.0819 \\
& -.0021 & -.0024 & & & $(11.01)$ \\
Beer Tax & $(3.75)$ & $(4.52)$ & & & $-8.1 \mathrm{E}-4$ \\
Minimum Legal Drinking & & & & & $(0.44)$ \\
Age & & & & & \\
\end{tabular}

\section{Motor Vehicle Fatality Rate}

$\begin{array}{ll}\text { National Unemployment } & -.0468 \\ \text { Rate } & (5.15)\end{array}$

State Unemployment Rate

$\begin{array}{llll}-.0308 & -.0239 & -.0311 & -.0316 \\ (6.30) & (4.04) & (12.96) & (13.53)\end{array}$

Time

.0191

.0126

(1.63) (1.12)

Time Squared

$-.0024$

$-.0018$

(3.09)

(2.49)

Beer Tax

Minimum Legal Drinking

$-.0125$

Age

\begin{tabular}{|c|c|c|c|c|c|}
\hline Dummy Variables Included & None & None & Year & $\begin{array}{c}\text { Year \& } \\
\text { State }\end{array}$ & $\begin{array}{c}\text { Year \& } \\
\text { State }\end{array}$ \\
\hline
\end{tabular}

Notes: The first panel estimates the model $\ln Y_{i}=X_{i} \beta+\mu_{i}$ by ordinary least squares. The second panel estimates the grouped data logit model $\ln \left(\frac{Y_{1}}{1-Y_{1}}\right)=X, \beta+\mu_{1}$, using weighted least squares. Pooled data are used for the 48 contiguous states for the period 1975 through 1988. Absolute value of $t$ statistics are shown in parentheses. $\mathrm{N}=652$. 
Table 4:

Fixed Effect Estimates of the Relationship

Between State Unemployment Rates and Alcobol Outcomes

Regressor

(a)

(b)

(c)

(d)

\section{Total Alcohol Consumption}

$\begin{array}{lcccc}\text { Unemployment Rate at t } & -.0062 & -.0060 & -.0058 & -.0020 \\ & (6.69) & (3.83) & (3.63) & (1.65) \\ \text { Unemployment Rate at t-1 } & & -2.6 \mathrm{E}-4 & -.0011 & \\ & & (0.16) & (0.50) & \\ \text { Unemployment Rate at t-2 } & & & 9.9 \mathrm{E}-4 & \\ & & & (0.60) & \end{array}$

Personal Income at $t$ (in $\$ 1000)$

\section{Motor Vehicle Fatality Rate}

$\begin{array}{lcccc}\text { Unemployment Rate at t } & -.0316 & -.0292 & -.0279 & -.0206 \\ & (13.53) & (7.59) & (7.20) & (6.75) \\ \text { Unemployment Rate at t-1 } & & -.0031 & -.0105 & \\ & & (0.80) & (2.01) & \\ \text { Unemployment Rate at t-2 } & & & .0073 & \\ & & & (1.83) & \\ \text { Personal Income at } t \text { (in \$1000) } & & & .0403 \\ & & & & (5.49)\end{array}$

Notes: See notes on table 3. All specifications include year and state dummy variables, covariates for beer taxes and minimum legal drinking ages, and control for state (rather than national) unemployment rates. Sample sizes are 652 for models (a) and (d), 632 for model (b), and 612 for model (c). 
Table 5:

Fixed Effect Estimates of the Relationship Between Percent of Population Employed and Alcohol Outcomes

\section{Regressor}

(a)

(b)

(c)

Total Alcohol Consumption

$\begin{array}{lccc}\text { \% of Population Employed at t } & .0079 & .0083 & .0043 \\ & (7.76) & (5.20) & (3.43) \\ \text { \% of Population Employed at t-1 } & & .0021 & \\ & & (1.05) & \\ \text { \% of Population Employed at t-2 } & -.0040 & \\ & & (2.49) & \\ \text { Personal Income (in } \$ 1000) & & .0124 \\ & & (4.70)\end{array}$

Motor Vehicle Fatality Rate

$\%$ Of Population Employed at $\mathrm{t}$ .0284 (10.71) .0294 (7.35) .0133

$\%$ of Population Employed at $t-1$ .0115

$\%$ of Population Employed at $\mathrm{t}-2$ (2.20) $-.0185$

Personal Income (in \$1000) (4.61)

Notes: See notes on tables 3 and 4. 
Table 6:

Fixed Effect Estimates of the Relationship Between

State Economic Conditions and Various Types of Alcohol Consumption

\section{Proxy for Economic Conditions}

$\begin{array}{ll}\text { Regressor } & \begin{array}{c}\% \text { of Population } \\ \text { Employed }\end{array}\end{array}$
(a)
(b)
(c)
(d)

\section{Total Alcohol Consumption}

$\begin{array}{lllll}\text { Economic Conditions at t } & -.0062 & -.0020 & .0079 & .0043 \\ & (6.69) & (1.65) & (7.76) & (3.43) \\ \text { Personal Income at } \mathrm{t} \text { (in } & & .0148 & & .0124 \\ \$ 1000) & & (5.25) & & (4.70)\end{array}$

\section{Consumption of Beer}

Economic Conditions at $\mathrm{t}$

$$
-.0036
$$

$-7.9 \mathrm{E}-6$

Personal Income at $\mathrm{t}$ (in

.0125

.0090

$\$ 1000$ )

$$
\text { (3.47) }
$$

\section{Consumption of Spirits}

$\begin{array}{lllll}\text { Economic Conditions at t } & -.0112 & -.0047 & .0132 & .0072 \\ & (7.61) & (2.45) & (8.05) & (3.47) \\ \text { Personal Income at } \mathrm{t} \text { (in } & & .0230 & & .0214 \\ \$ 1000) & & (5.09) & & (5.06)\end{array}$

\section{Consumption of Wine}

$\begin{array}{lllll}\text { Economic Conditions at t } & -.0038 & -.0024 & .0091 & .0104 \\ & (0.88) & (0.42) & (1.89) & (1.72) \\ \text { Personal Income at } t \text { (in } & & .0049 & & -.0046 \\ \$ 1000) & & (0.36) & & (0.36)\end{array}$

Notes: See notes on tables 3 and 4. 
Tahle 7:

Fixed Effect Estimates of the Relationship Between State Unemployment Rates and Various Types of Motor Vehicle Fatalities

Regressor

Motor Vehicle Fatality Rate

(a)

All Individuals
Night-time Motor Vehicle Fatality Rate

(c)

(d)

\begin{tabular}{lcccc}
\multicolumn{5}{c}{ All Individuals } \\
\\
Unemployment Rate at t & -.0316 & -.0206 & -.0133 & -.0093 \\
& $(13.53)$ & $(6.75)$ & $(3.41)$ & $(1.76)$ \\
& {$[.232]$} & {$[.151]$} & {$[.098]$} & {$[.068]$} \\
Personai Income at t (in & & .0403 & & .0145 \\
\$1000) & & $(5.49)$ & & $(1.14)$ \\
& & {$[.566]$} & & {$[.150]$} \\
\hline
\end{tabular}

15-20 Year Olds

$\begin{array}{lllll}\text { Unemployment Rate at t } & -.0205 & -.0155 & -.0074 & -.0151 \\ & (6.24) & (3.55) & (1.30) & (1.97) \\ & {[.150]} & {[.114]} & {[.054]} & {[.111]} \\ \text { Personal Income at } t \text { (in } & & .0184 & & -.0281 \\ \$ 1000) & & (1.75) & & (1.50) \\ & & {[.258]} & & {[.394]}\end{array}$

\section{1-24 Year Olds}

$\begin{array}{lllll}\text { Unemployment Rate at t } & -.0314 & -.0197 & -.0160 & -.0114 \\ & (8.12) & (3.84) & (2.70) & (1.44) \\ & {[.230]} & {[.145]} & {[.117]} & {[.084]} \\ \text { Personal Income at t (in } & & .0422 & & .0163 \\ \text { \$1000) } & & (3.44) & & (0.86) \\ & & {[.593]} & & {[.229]}\end{array}$

Notes: See notes on tables 3 and 4 . Night-time vehicle fatalities include fatal crashes occurring between 12:00 and 3:59 a.m. Absolute value of estimated elasticities shown in brackets.

Elasticities estimated as $\varepsilon_{j}=(1-\bar{P}) \hat{\beta}_{j} \bar{X}_{j}$, where $\hat{\beta}_{j}$ is the logit coefficient of the jth regressor and $\bar{X}_{j}$ and $\bar{P}$ are the sample means of the jexplanatory variable and the motor vehicle fatality rate respectively. 
Fig. 1: Time Trends in Selected Variables

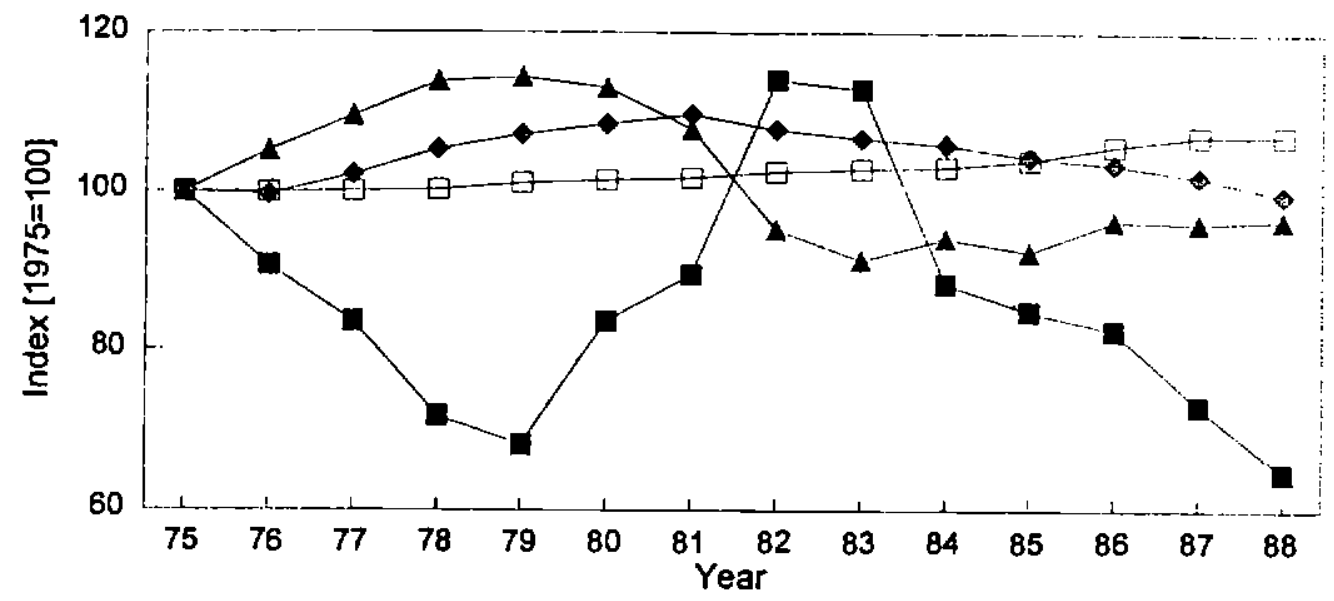

- Unemployment Rate $\bullet$ Alcohol Consumption $\star$ Vehicle Fatalities $\in$ Drinking Age 
Fig. 2: Unemployment Rale in U.S. and Selected States

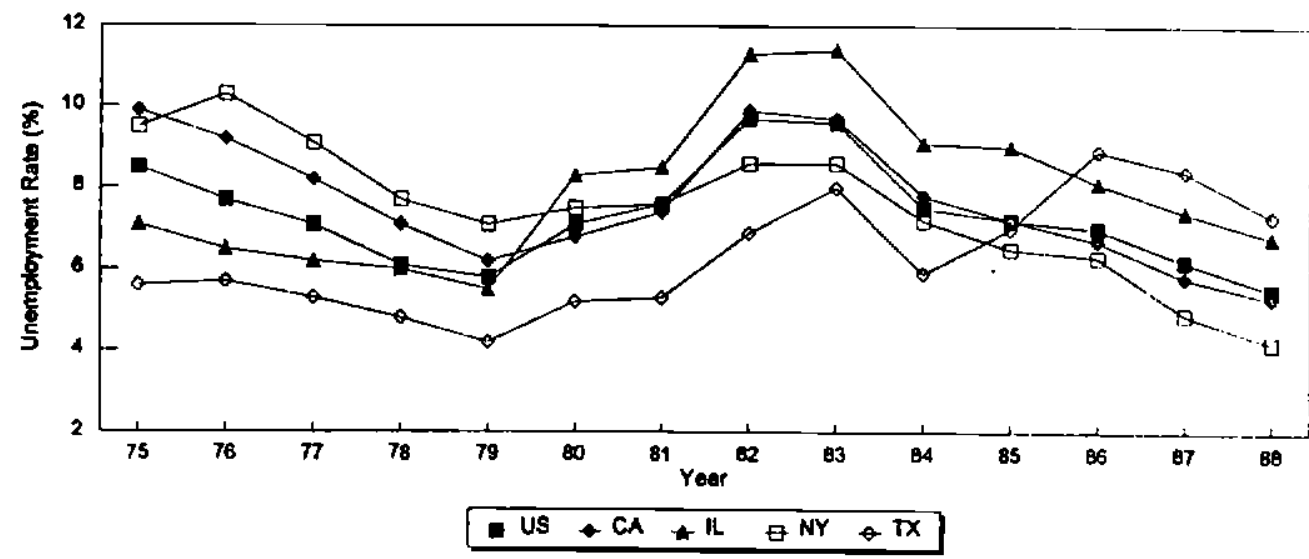

Fig. 3: Employment-to-Population Ratio in U.S. and Selecled States

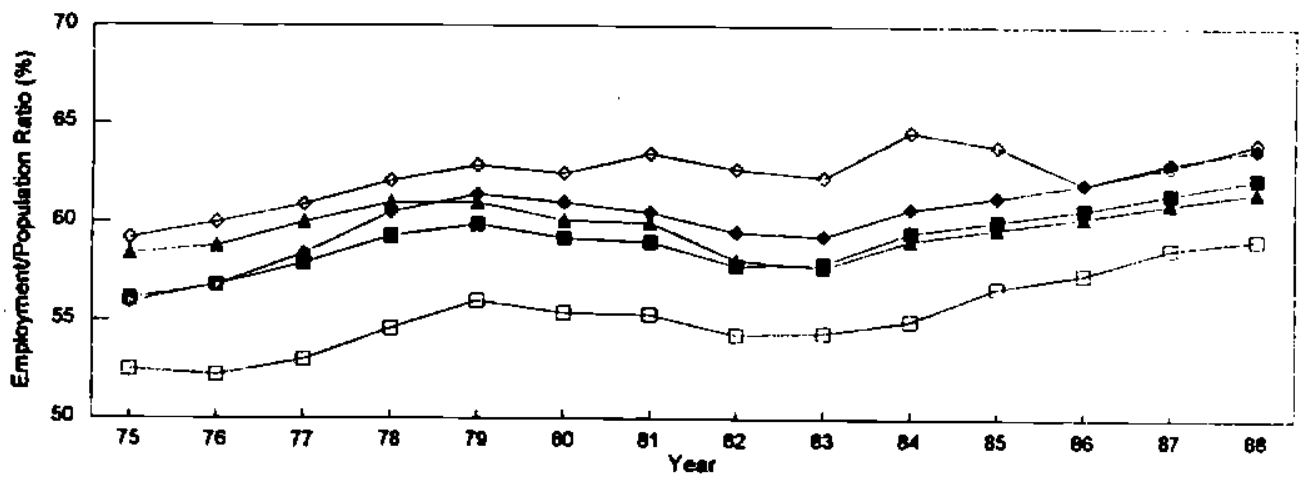

E US $\leftarrow \mathrm{CA}+\mathrm{IL} E \mathrm{NY} \oplus \mathrm{TX}$

Fig 4: Change in Gross Domestic Product In U.S. and Selected Stales

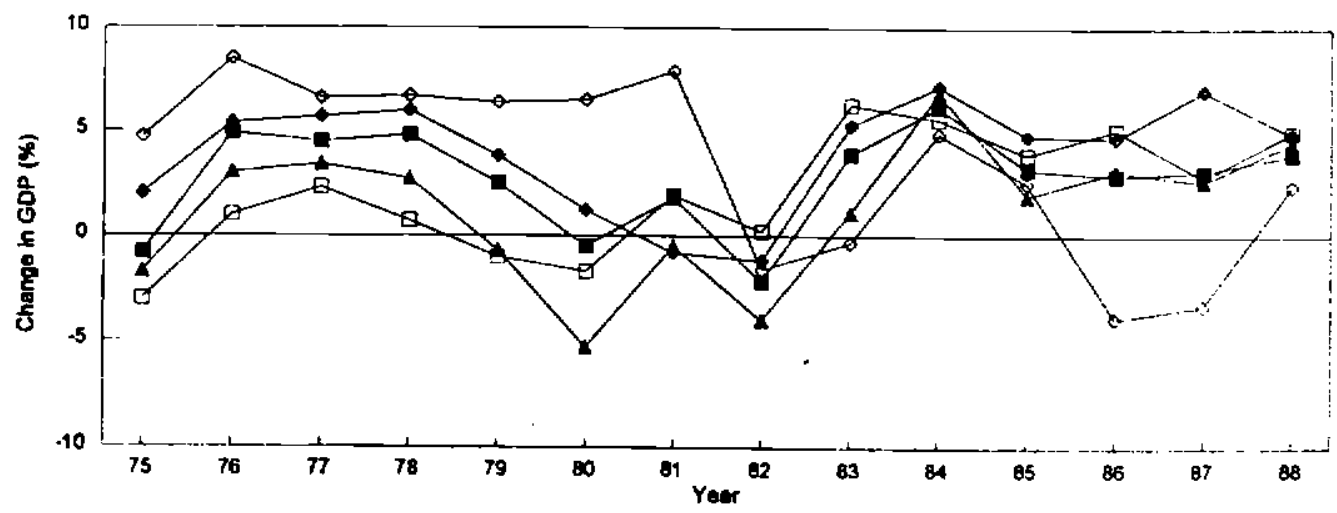

$=U S+C A+I L \quad E N+T X$ 
To order any of these papers, see instructions at the end of the list. To subscribe to all NBER Working Papers or the papers in a single area, see instructions inside the back cover. A complete list of NBER Working Papers and Reprints can be accessed on the Internet by using our gopber at nber.harvard.edu.

\begin{tabular}{|c|c|}
\hline Number & Author(s) \\
\hline 4856 & Hans-Wemer Sinn \\
\hline 4857 & $\begin{array}{l}\text { Niko Canner } \\
\text { N. Gregory Mankiw } \\
\text { David N. Weil }\end{array}$ \\
\hline 4858 & $\begin{array}{l}\text { James Dow } \\
\text { Gary Gorton }\end{array}$ \\
\hline 4859 & $\begin{array}{l}\text { Francis X. Diebold } \\
\text { David Neumark } \\
\text { Daniel Polsky }\end{array}$ \\
\hline 4860 & $\begin{array}{l}\text { Michael D. Bordo } \\
\text { Anna J. Schwartz }\end{array}$ \\
\hline 4861 & $\begin{array}{l}\text { David Genesove } \\
\text { Chrislopher J. Mayer }\end{array}$ \\
\hline 4862 & $\begin{array}{l}\text { Don Fullerton } \\
\text { Diane Lim Rogers }\end{array}$ \\
\hline 4863 & G. William Schwert \\
\hline 4864 & $\begin{array}{l}\text { Enrique G. Mendoza } \\
\text { Assaf Razin } \\
\text { Linda L. Tesar }\end{array}$ \\
\hline 4865 & $\begin{array}{l}\text { Jeffrey A. Frankel } \\
\text { Andrew K. Rose }\end{array}$ \\
\hline 4866 & Gcorge J. Borjas \\
\hline 4867 & $\begin{array}{l}\text { Joel Slemrod } \\
\text { Carl Hansen } \\
\text { Roger Procter }\end{array}$ \\
\hline 4868 & Louis Kaplow \\
\hline 4869 & $\begin{array}{l}\text { Harry Grubert } \\
\text { Joel Slemrod }\end{array}$ \\
\hline 4870 & Dani Rodrik \\
\hline
\end{tabular}

$\underline{\text { Tille }}$

Date

A Theory of the Welfare State

An Asset Allocation Puzzle

$9 / 94$

Noise Trading, Delegated Portfolio

9/94

Management, and Economic Welfare

9/94

Job Stability in the United States

9/94

The Specie Standard as a Contingent Rule:

Some Evidence for Core and Peripheral

Countries, 1880-1990

Equity and Time to Sale in the Real

9/94

Estate Market

Distributional Effects on a Lifetime Basis

9/94

Mark-Up Pricing in Mergers and Acquisitions

9/94

Effective Tax Rates in Macroeconomics:

9/94

Cross-Country Estimates of Tax Rates

on Factor Incomes and Consumption

A Survey of Empirical Research

$9 / 94$

on Nominal Exchange Rates

Assimilalion and Changes in Cohort Quality

Revisited: What Happened to Immigrant

Earnings in the 1980s?

The Seesaw Principle in International

Tax Policy

9/94

A Note on Subsidizing Gifts

9/94

The Effect of Taxes on Investment and

9/94

Income Shifting to Puerto Rico

What Does the Political Economy Literature on Trade Policy (Not) Tell Us That We

9/94

Ought to Know? 
To order any of these papers, see instructions at the end of the list. To subscribe to all NBER Working Papers or the papers in a single area, see instructions inside the back cover. A complete list of NBER Working Papers and Reprints can be accessed on the Internet by using our gopher at nber.barvard.edu.

\begin{tabular}{|c|c|}
\hline Number & Author(s) \\
\hline 4871 & Lars E. O. Svensson \\
\hline 4872 & George J. Borjas \\
\hline 4873 & $\begin{array}{l}\text { Jose De Gregorio } \\
\text { Federico Sturzenegger }\end{array}$ \\
\hline 4874 & $\begin{array}{l}\text { Brandice J. Canes } \\
\text { Harvey S. Rosen }\end{array}$ \\
\hline 4875 & $\begin{array}{l}\text { Raghuram G. Rajan } \\
\text { Luigi Zingales }\end{array}$ \\
\hline 4876 & $\begin{array}{l}\text { Gene Grossman } \\
\text { Elhanan Helpman }\end{array}$ \\
\hline 4877 & $\begin{array}{l}\text { Gene Grossman } \\
\text { Elhanan Helpman }\end{array}$ \\
\hline 4878 & $\begin{array}{l}\text { C. Keith Head } \\
\text { John C. Ries } \\
\text { Deborah L. Swenson }\end{array}$ \\
\hline 4879 & David M. Cutler \\
\hline 4880 & $\begin{array}{l}\text { Douglas Holtz-Eakin } \\
\text { John R. Penrod } \\
\text { Harvey S. Rosen }\end{array}$ \\
\hline 4881 & $\begin{array}{l}\text { Nouriel Roubini } \\
\text { Gian Maria Milesi-Ferretti }\end{array}$ \\
\hline 4882 & $\begin{array}{l}\text { Nouriel Roubini } \\
\text { Gian Maria Milesi-Ferretti }\end{array}$ \\
\hline 4883 & $\begin{array}{l}\text { Raquel Fernandez } \\
\text { Richard Rogerson }\end{array}$ \\
\hline 4884 & $\begin{array}{l}\text { R. Glenn Hubbard } \\
\text { Jonathan Skinner } \\
\text { Stephen P. Zeldes }\end{array}$ \\
\hline 4885 & Martin Feldstein \\
\hline 4886 & $\begin{array}{l}\text { Oliver Hart } \\
\text { John Moore }\end{array}$ \\
\hline
\end{tabular}

$\underline{\text { Title }}$

Dale

Estimating and Interpreting Forward $\quad 9 / 94$ Interest Rates: Sweden 1992-1994

Immigration and Welfare, 1970-1990

$9 / 94$

Credit Markets and the Welfare Costs 10/94 of Inflation

Following in Her Footsteps? Women's Choices 10/94 of College Majors and Faculty Gender Composition

What Do We Know about Capital Structure? $10 / 94$ Some Evidence from Inlemational Data

Foreign Investment with Endogenous Protection 10/94

Electoral Competition and Special Interest Politics

$10 / 94$

The Attraction of Foreign Manufacturing

$10 / 94$ Investments: Investment Promotion and Agglomeralion Economies

Market Failure in Small Group Health Insurnnce $\quad 10 / 94$

Health Insurance and the Supply of

$10 / 94$

Entrepreneurs

Taxation and Endogenous Growth in Open

$10 / 94$

Economies

Optimal Taxation of Human and Physical Capital 10/94

in Endogenous Growth Models

Public Education and Income Distribution: A $10 / 94$ Quantitative Evaluation of Education Finance Reform

Precaulionary Saving and Social Insurance

$10 / 94$

Fiscal Policies, Capital Formation and Capitalism $10 / 94$

Debt and Seniority: An Analysis of the Role of Hard Claims in Constraining Management

$10 / 94$ 
To order any of these papers, see instructions at the end of the list. To subscribe to all NBER Working Papers or the papers in a single aren, see instructions inside the back cover. A complete list of NBER Working Papers and Reprints can be accessed on the Internet by using our gopher at nber.harvard.edu.

\begin{tabular}{|c|c|}
\hline Number & Author(s) \\
\hline 4887 & $\begin{array}{l}\text { Ricardo J. Caballero } \\
\text { Eduardo M.R.A. Engel }\end{array}$ \\
\hline 4888 & $\begin{array}{l}\text { Martin Feldstein } \\
\text { James H. Stock }\end{array}$ \\
\hline 4889 & $\begin{array}{l}\text { Mark Hooker } \\
\text { Michael Knetter }\end{array}$ \\
\hline 4890 & $\begin{array}{l}\text { John R. Graham } \\
\text { Campbell R. Harvey }\end{array}$ \\
\hline 4891 & W. Kip Viscusi \\
\hline 4892 & Alan M. Taylor \\
\hline 4893 & $\begin{array}{l}\text { Maurice Obstfeld } \\
\text { Kenneth Rogoff }\end{array}$ \\
\hline 4894 & Michael M. Knetter \\
\hline 4895 & Peter Diamond \\
\hline 4896 & Lawrence H. Goulder \\
\hline
\end{tabular}

Title

Date

Explaining Investment Dynamics in U.S.

$10 / 94$ Manufacturing: A Generalized (S,s) Approach

Measuring Money Growth When Financial

$10 / 94$

Markets Are Changing

Unemployment Effects of Military Spending:

Evidence from a Panel of States

Market Timing Ability and Volatility

Implied in Investment Newsletters*

Asset Allocation Recommendations

Cigarette Taxation and the Social

Consequences of Smoking

Domestic Saving and International

Capital Flows Reconsidered

The Intertemporal Approsch to the

Current Account

Why Are Relail Prices in Japan So High?:

Evidence from German Expart Prices

Insulation of Pensions from Political Risk

$10 / 94$

Environmental Taxation and the "Double

$10 / 94$

Dividend": A Reader's Guide

Optimal Environmental Taxation in the Presence of Other Taxes: General Equilibrium Analyses

Speculative Attacks on Pegged Exchange Rates: An Empirical Exploration with Special Reference to the European Monetary System

From Superminis to Supercomputers: Estimating Surplus in the Computing Market

IRAs and Household Saving Revisited: Some New Evidence

The Competitive Crash in Large-Scale Commercial Computing
$10 / 94$ 
To order any of these papers, see instructions at the end of the list. To subscribe to all NBER Working Papers or the papers in a single area, see instructions inside the back cover. A complete list of NBER Working Papers and Reprints can be accessed on the Internet by using our gopher at aber.harvard.edu.

\begin{tabular}{|c|c|c|c|}
\hline Number & Author(s) & Title & Date \\
\hline 4902 & Joel Slemrod & Free Trade Taxation and Protectionist Taxation & $10 / 94$ \\
\hline 4903 & $\begin{array}{l}\text { Assaf Razin } \\
\text { Efraim Sadka }\end{array}$ & $\begin{array}{l}\text { Resisting Migration: The Problems of Wage } \\
\text { Rigidity and the Social Burden }\end{array}$ & $10 / 94$ \\
\hline 4904 & $\begin{array}{l}\text { Emst R. Bemdt } \\
\text { Linda Bui } \\
\text { David Reiley } \\
\text { Glen Urban }\end{array}$ & $\begin{array}{l}\text { The Roles of Marketing. Product Quality and } \\
\text { Price Competition in the Growth and } \\
\text { Composition of the U.S. Anti-UIcer } \\
\text { Drug Industry }\end{array}$ & $10 / 94$ \\
\hline 4905 & $\begin{array}{l}\text { Thomas C. Kinnaman } \\
\text { Don Fullerton }\end{array}$ & $\begin{array}{l}\text { How a Fee Per-Unil Garbage Aftects } \\
\text { Aggregate Recycling in a Model with } \\
\text { Heterogeneous Households }\end{array}$ & $10 / 94$ \\
\hline 4906 & Daniel S. Hamermesh & $\begin{array}{l}\text { Aging and Productivity, Rationality and } \\
\text { Matching: Evidence from Economists }\end{array}$ & $10 / 94$ \\
\hline 4907 & $\begin{array}{l}\text { Kooyul Jung } \\
\text { Yong-Cheol Kim } \\
\text { René M. Stulz }\end{array}$ & $\begin{array}{l}\text { Investment Opportunities, Managerial } \\
\text { Discretion, and the Security Issue } \\
\text { Decision }\end{array}$ & $10 / 94$ \\
\hline 4908 & $\begin{array}{l}\text { Jun-Koo Kang } \\
\text { René M. Stulz }\end{array}$ & $\begin{array}{l}\text { How Different is Japanese Corporate } \\
\text { Finance? An Investigation of the } \\
\text { Information Content of New Security Issues }\end{array}$ & $10 / 94$ \\
\hline 4909 & Robert J. Barro & Democracy and Growth & 10,94 \\
\hline 4910 & Richard B. Freeman & Crime and the Job Market & 10,94 \\
\hline 4911 & Rebecca M. Blank & The Dynamics of Part-Time Work & $11 / 94$ \\
\hline 4912 & George J. Borj3s & $\begin{array}{l}\text { Ethricity, Neighborhoods, and Human Capital } \\
\text { Externalities }\end{array}$ & $11 / 94$ \\
\hline 4913 & $\begin{array}{l}\text { George J. Borjas } \\
\text { Bernt Britsberg }\end{array}$ & $\begin{array}{l}\text { Who Leaves? The Outmigration of the } \\
\text { Foreign-Bom }\end{array}$ & $11 / 94$ \\
\hline 4914 & Christopher J. Ruhm & Economic Conditions and Alcohol Problems & $11 / 94$ \\
\hline
\end{tabular}

Copies of the above working pàpers can be obtained by sending $\$ 5.00$ per copy (plus $\$ 10.00$ per order for postage and handling for all locations outside the continental U.S.) to Working Papers, NBER, 1050 Massachusetts Avenue, Cambridge, MA 02138-5398. Advance payment is required on all orders. Payment may be made by check or credit card. Checks should be made payable to the NBER and must be in dollars drawn on a U.S. bank. If paying by credit card, include the cardholder's name, account number and expiration date. For all mail orders, please be sure to include your retum address and telephone number. Working papers may also be ordered by telephone $(617-868-3900)$, or by fax (617-868-2742). 


\section{National Bureau of Economic Research}

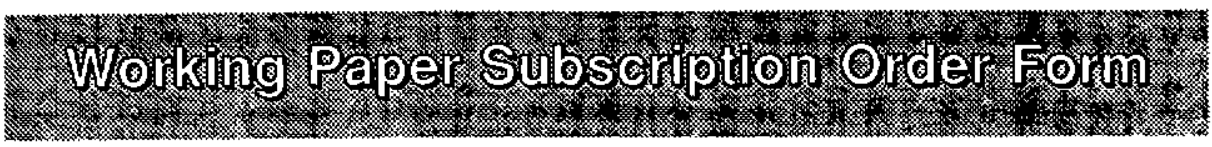

口 Full subscriptions*

$\begin{array}{lc} & \text { Academic Libraries/ } \\ \text { Standard } & \text { Faculy Members } \\ \$ 1300 & \$ 650\end{array}$

Foreign"*
Srandard Academic Librariest
$\$ 1625$

Partial subscriptions

D Corporate Finance

- Stocks, Bonds, and Foreign Currency

300

75

$\begin{array}{ll}350 & 110\end{array}$

- Intemational Finance and Macroeconomics

300

75

135

135

270

150

口 Monetary Economics

Economic Fluctuations

- Long-Run Economic Growth

- Sources of Productivity Growth

- Taxation

- Labor Studies

Economics of Health and Heatth Care

270

150

70

270

270

150

I Economics of the Elderty

$\square$ Industrial Organization

口 Technical Working Papers

- Historical Development of the American Econormy 70

$\begin{array}{rr}350 & 110 \\ 350 & 110 \\ 350 & 210 \\ 350 & 210 \\ 200 & 110 \\ 350 & 210 \\ 200 & 110 \\ 85 & 50 \\ 350 & 210 \\ 350 & 210 \\ 200 & 110 \\ 85 & 50 \\ 85 & 50 \\ 85 & 50 \\ 85 & 50\end{array}$

- A full subscription includes all topics listed under "partial subscriptions" except for Technical Working Papers and papers on the Historical Development of the American Economy. These must be ordered in addition to the tuli subscription.

- Please inquire about subscription prices for Avrica and Australia.

\section{PAYMENT OPTIONS}

YES! Please begin my subscription so the NBER Working Paper Series. I have indicased above which papers I would like to receive.

By Phone: (617) 868-3900

By FAX: (617) $868-2742$

By Mail: Publications Department

National Bureau of Economic Research 1050 Massachusetts Ave. Cambridge, MA 02138

$\square$ Payment in the amount of enclosed.

$\square$ Please charge my: $\square$ VISA $\square$ MasterCard

Cand Number:

Card expiration:

Signature:
Please mail my papers to this address:

Name

Address

Phone:

FAX: 